\title{
Latest Developments of Palm Oil as a Sustainable Transformer Fluid: A Green Alternative to Mineral Oils
}

\author{
Muhammad Hakirin Roslan ${ }^{1(\mathbb{D})}$, Nur Aqilah Mohamad ${ }^{1,2}{ }^{\mathbb{D}}$, Thien Yee Von ${ }^{1(\mathbb{D})}$, \\ Hadi Mahdi Zadeh ${ }^{3(\mathbb{D})}$, Chandima Gomes 4 ,* (D)
}

1 Department of Electrical and Electronics Engineering, Universiti Putra Malaysia, Malaysia; hakirinroslan@gmail.com (M.H.R.); qieylaqilah@gmail.com (N.A.M.); yvonne.thien@gmail.com (T.Y.V.);

2 Department of Electrical Engineering, Politeknik Mukah, Malaysia

3 Department of Mechanical and Manufacturing Engineering, Universiti Putra Malaysia, Malaysia; hadi.mzh@icloud.com (H.M.Z.);

4 School of Electrical and Information Engineering, University of Witwatersrand, South Africa; chandima.gomes@wits.ac.za (C.G.);

* Correspondence: chandima.gomes@wits.ac.za;

Scopus Author ID 57201335285

Received: 7.01.2021; Revised: 5.02.2021; Accepted: 9.02.2021; Published: 15.02.2021

\begin{abstract}
Increasing awareness of safety and the environment demands the replacement of mineral oil by bio-oils in many electrical applications. Palm oil has been identified as a potential candidate for mineral oil in transformers. This study reviews the physio-chemical and electrical properties of palm oil as insulation fluid. Analysis of electrical properties has been conducted on AC and lightning impulse breakdown voltage and dielectric parameters, whereas physicochemical properties are discussed in terms of viscosity, acidity, and moisture. The performance of palm oil under aging and pressure is also presented. Several case studies of palm oil in the presence of nanoparticles have been reviewed. Concerning economic and technical perspectives, palm oil has a significantly high potential as a transformer fluid. Further studies on the suitability of palm oil as a transformer fluid is required to evaluate the long-term performance concerning partial discharge, transient energy, aging performance under various ambient conditions, and in the presence of suspended nanoparticles.
\end{abstract}

Keywords: insulation fluid; palm oil; transformer; coolant; breakdown voltage; bio-oils.

(C) 2021 by the authors. This article is an open-access article distributed under the terms and conditions of the Creative Commons Attribution (CC BY) license (https://creativecommons.org/licenses/by/4.0/).

\section{Introduction}

For the last few decades, agro-based oils and seed extracts have been extensively used in many industrial spheres for various applications, ranging from antidiabetic medicine to prawn feeds [1-4]. Many of these researches were on edible products (for either human or animal consumption); however, agro-oils usage is now way beyond these conventional applications [5].

In electrical power systems, the transformer is one of the most critical and expensive assets. The oil-filled type transformers are widely used in power system networks where the main components are winding, core, tank, and oil. The oil, also known as insulation fluid, insulates the electrical stress and acts as a cooling medium by dissipating heat generated from transformer winding and cores. Many theoretical and experimental investigations have shown that transformer fluid is both a cause and an indicator of transformer health degradation [6-7]. Mineral oil is widely used as an insulation fluid in transformer applications due to its excellent dielectric and cooling properties. Despite the excellent performance of mineral oil, it is non- 
biodegradable and non-renewable. The past decade has seen the rapid development of a more environment-friendly product such as vegetable oil instead of mineral oil. Palm oil is one of the key vegetable oils that possess high flash/fire points, long-term environmentally friendly performance, and non-toxic properties that could be used for the purpose. It is a natural product that is abundant in the environment [8-10]. In recent years, palm oil has been identified as a potential candidate to replace the mineral oil as transformer insulation fluid [11-16].

Before any alternative fluid is practically introduced as insulation fluid in transformers, their physical, chemical, and electrical characteristics should be thoroughly investigated [17]. In terms of electrical characteristics, the evaluation $\mathrm{f}$ electrical performance parameters such as $\mathrm{AC}$ and lightning impulse breakdown strength, dielectric properties, partial discharge, and dielectric dissipation factor needs to be carried out. For AC and lightning impulse breakdown strength, it is important to investigate the palm oil's breakdown voltage under various electrode configurations. It is crucial for insulation fluid to have a high breakdown voltage in order to withstand electrical stress.

Studies on dielectric properties include dielectric dissipation factor, relative permittivity, and resistivity. Relative permittivity can be used to determine the types of dielectric where low relative permittivity shows that the material is not suitable to be used as insulation fluid [18]. The studies about the dielectric dissipation factor are also an indicator in evaluating the dielectric losses and determining the presence of contamination in the oil. The assessment of palm oil's physicochemical properties such as viscosity, moisture, and acidity needs to be investigated to determine the mechanism that can lead to total or partial transformer failures [18]. The viscosity of palm oil is important to determine the insulation fluid cooling capability and its oxidation stability [19-20]. Determination of moisture in palm oil also needs to be examined because moisture is known as the main cause of the aging mechanism.

At the moment, several studies have been conducted to study the effect of adding nanoparticles (nanotechnology) in insulation fluid to enhance its properties [21-23]. The findings suggest that palm oil performance as an insulation fluid has been improved with the addition of nanoparticles [24-26].

In the recent past, several review and semi-review papers have been published on the suitability of bio-oils as a transformer insulation fluid [9, 27-28, 29 - 30]. However, in all these studies, palm oil has been discussed only peripherally, as their major focus was on some other ester oils. On the other hand, being the largest palm oil producer globally, the South East Asian trio, Malaysia, Indonesia, and Thailand, have conducted a significant amount of research during the last few years on the application of palm oil as a transformer fluid. However, a comprehensive review has not been carried out in this regard in the recent past. Thus, this study has been conducted to fulfill this existing information gap in the literature. The review has been done in terms of palm oil properties and performances as an insulation fluid. For palm oil properties, a review related to electrical (AC and lightning impulse breakdown voltage and dielectric dissipation factor) and physicochemical properties (viscosity, acidity and moisture) is carried out. In terms of palm oil performance, the investigations have been carried out related to properties of palm oil under aging [15], and the available information has been critically discussed. Studies on nanoparticles in palm oil have also been reviewed in this study to identify the improvisation of palm oil as an insulation fluid with the presence of nanoparticles $[15,25,31,32]$. 


\section{Materials and Methods}

\subsection{Types of palm oil.}

Palm Oil is natural ester oil which can be extracted from fruits processing of oil palm tree called palm nuts. Practically, it is an edible oil that consists of a hard seed (kernel) covered by a shell (endocarp), which is surrounded by a flush husk (mesocarp) [33]. There are five different types of Palm Oil that can be obtained from palm nuts; Crude Palm Oil (CPO), Palm Kernel Oil (PKO), Redefined, Bleached and Deodorized Palm Oil (RBDPO), PKO Alkyl Ester (PKOAE), and Palm Fatty Acid Ester (PFAE). The descriptions of each type of Palm Oil are tabulated in Table 1.

Table 1. Description of the types of Palm Oil.

\begin{tabular}{|c|c|c|}
\hline Types of Palm Oil & Description & References \\
\hline $\begin{array}{l}\text { Crude Palm Oil } \\
\text { (CPO) }\end{array}$ & $\begin{array}{l}\text { Can be obtained from the mesocarp of the palm nut via } \\
\text { four processes: } \\
\text { - Sterilization } \\
\text { - Stripping } \\
\text { - Extraction } \\
\text { - } \quad \text { Purification }\end{array}$ & {$[1,4,34]$} \\
\hline $\begin{array}{l}\text { Palm Kernel Oil } \\
\text { (PKO) }\end{array}$ & $\begin{array}{l}\text { Can be obtained from the kernel of the palm nut via two } \\
\text { processes: } \\
\text { - Separation } \\
\text { - } \quad \text { Drying }\end{array}$ & {$[1,4,34]$} \\
\hline $\begin{array}{l}\text { Redefined, Bleached } \\
\text { and Deodorized Palm } \\
\text { Oil } \\
\text { (RBDPO) }\end{array}$ & $\begin{array}{l}\text { Can be refined through three different techniques: } \\
\text { - Under degumming } \\
\text { - Bleaching } \\
\text { Can be separated through fractionation process to produce } \\
\text { the RBDPO Olein. }\end{array}$ & {$[4,34,35]$} \\
\hline PKO Alkyl Ester & $\begin{array}{l}\text { Can be synthesized by three different techniques: } \\
\text { - Transesterification } \\
\text { - Epoxidation } \\
\text { - } \quad \text { Acid catalysed ring opening reaction } \\
\end{array}$ & {$[4,34,35]$} \\
\hline $\begin{array}{l}\text { Palm Fatty Acid Ester } \\
\text { (PFAE) }\end{array}$ & $\begin{array}{l}\text { Can be obtained from the unsaturated fatty acids of Palm } \\
\text { Oil and developed through laboratory synthesis involving: } \\
\text { - Molecular design } \\
\text { - Transesterification of fatty acid methyl ester and } \\
\text { alkyl alcohol }\end{array}$ & {$[36,37]$} \\
\hline
\end{tabular}

\subsection{Electrical properties of palm oil.}

$\mathrm{AC}$ and impulse voltage tests are the two most common methods that are used to determine the breakdown voltage of dielectric insulation in transformers [38]. The studies on the dielectric properties such as dielectric dissipation factor, resistivity, and relative permittivity also need to be carried out to examine palm oil's suitability as insulation fluid.

\subsubsection{Breakdown voltage under AC $(50 / 60 \mathrm{~Hz})$.}

The AC breakdown voltage is the most common and widely used basic electrical test for insulation fluid, which is applied under high voltage environments and is normally carried out at a nominal frequency of $50 \mathrm{~Hz}$ or $60 \mathrm{~Hz}$ [39]. The AC breakdown voltages are measured based on ASTM D1816 [40] and IEC 60156 [41] standards. Based on IEC 60156 [41] specifications, insulation fluids must satisfy the minimum breakdown voltage level of $30 \mathrm{kV}$ to be qualified as a transformer fluid [42]. The hemispherical shaped electrodes are used, and the electrodes gap distance is $2.5 \mathrm{~mm}$. Previous studies have shown that the AC breakdown performances for most of the Palm Oil formulations meet the requirement of the IEC standards 
$[11,16,43,44-48]$. Table 2 provides the breakdown values of palm oil from some of the studies available in the literature.

Table 2. AC breakdown of various types of Palm Oil.

\begin{tabular}{l|l} 
Palm Oil & VDE electrode $\mathbf{2 . 5} \mathbf{~ m m}$ gap at $\mathbf{~ V V} / \mathbf{m m}$ \\
\hline Requirement for transformer fluids $[40,41,42]$ & $>30 / 50$ \\
\hline CPO [48] & Between 17 and 23 \\
\hline RBDPO [15,48] & In the range 52,75 and 86 \\
\hline RBDPO olein $[14,15,16,48]$ & Between 44 and 60
\end{tabular}

2.2.2. Breakdown voltage under lightning and switching impulses.

IEEE Guide reported that the failures in high voltage applications caused by lightning are around 35\% [49]. The lightning current generates transient overvoltage, which affects the performance of the dielectric insulation fluid of transformers in-service. Switching operations (grid energizing/de-energizing, system faults and tripping, and other unexpected interruptions such as line breakage) also generate transient overvoltage.

The standard lightning and switching impulse waveforms are modeled by either the double exponential function or the Heidler function [50]. The two functions are somewhat similar; the double exponential waveform shows a discontinuity of the waveform derivative at $\mathrm{t}=0$ [51]. Thus, in much modern application, Heidler functions have been adopted to represent both lightning and switching waveforms. Figure 1 shows the standard waveform (based on the Heidler function) used in many applications. For lightning voltage impulse, T1 is $1.2 \mu \mathrm{s}$, and $\mathrm{T} 2$ is $50 \mu \mathrm{s}$. There are many switching voltage impulse waveforms, and a typical set of values are $\mathrm{T} 1=250 \mu \mathrm{s}$ and $\mathrm{T} 2=2500 \mu \mathrm{s}$. Both lightning and switching impulses can be produced using an impulse generator (typically called a Marx generator).

The failure of transformers in-service could be very costly to utilities; therefore the evaluation of dielectric insulation fluid performance under impulse voltage is important [52]. Hence, common tests of lightning impulse and switching impulse have been carried out to determine the ability of the insulation fluids in transformers to withstand the transient voltage and switching operation fault [53]. Lightning and switching impulse breakdown voltages can be measured according to the standard ASTM D3300 [54] and IEC 60897 [55]. Several studies have found that the impulse breakdown voltages for RBDPO Olein fulfilled the requirement of IEC 60897 [55], which are more than the minimum level breakdown voltages of 50kV [56], as shown in Table 3.

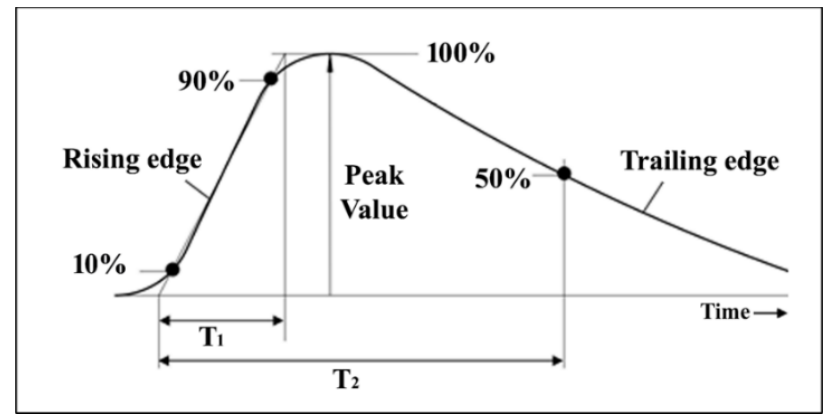

Figure 1. Standard lighting and switching impulse waveform, based on Heidler function.

Table 3. Lightning impulse breakdown of palm oil.

\begin{tabular}{c|c} 
Palm Oil & $\begin{array}{c}\text { Breakdown voltage (kV)at gap 15 } \\
\text { mm }\end{array}$ \\
\hline Requirement for transformer fluids [55] & $>50$ \\
\hline RBDPO olein [56] & Between 89 and 106
\end{tabular}




\subsubsection{Dielectric properties.}

\subsubsection{Dielectric dissipation factor.}

The dielectric dissipation factor is used to determine the quality of oil [57]. It is a good indicator to determine if there is any contamination in dielectric insulation fluid and also to evaluate dielectric losses of the fluid [58]. The insulation fluid contamination could be due to the moisture, particles, sedimentation, and soluble polar contaminants or poor refining quality. According to IEC 62770 [59], the standard acceptance value of the dielectric dissipation factor is less than 0.05. Based on the previous studies, palm oil's dielectric dissipation factor is slightly lower than the recommended limit of IEC standards [59], which is between 0.006 and 0.013 for CPO, RPO is ranging from 0.0114 to 0.013 , and RBDPO is between 0.0035 and 0.014 . The dielectric dissipation factor value of RBDPO olein is the highest among those three types of palm oil, with the value ranging between 0.0014 and 0.03 . The information is summarized in Table 4.

\subsubsection{Resistivity.}

Resistivity is defined as the ratio of the direct potential gradient in volts/meter parallel with the flow of current to the current density of the samples in amperes/meter square [58]. At present, no sufficient studies have been done on the resistivity of palm oil under various conditions. One of the available reports states that the resistivity of RBDPO is between 4.01 $\Omega \mathrm{m}$ and $6.22 \Omega \mathrm{m}$, which is lower than recommended limit suggested by IEC 62770 [59] for natural ester dielectric insulation fluid [13][16] (Table 5).

\subsubsection{Relative permittivity.}

Relative permittivity is used to determine the type of dielectric insulating fluid [60]. Relative permittivity can be described as a measurement of the resistance encountered in the formation of electric fields between the electrodes in the dielectric insulating medium [58]. The relative permittivity of crude palm oil is 2.1 , which is lower than the limit recommended by IEC 62770, whereas the relative permittivity of RBDPO is 3.5, which is slightly higher than the limit recommended by IEC 62770 [59] and previously discussed in Suwarno and Aditama [61] and Suwarno et al., [62]. Only relative permittivity for RBDPO olein is within the limit, which is 2.81 at $90{ }^{\circ} \mathrm{C}$ [16] (Table 6).

\subsection{Physicochemical properties of palm oil.}

Apart from electrical properties, it is necessary to evaluate palm oil's physicochemical properties to examine its insulation capabilities. The physicochemical properties are evaluated in terms of viscosity, acidity, and moisture.

\subsubsection{Viscosity.}

Viscosity is one of the important aspects of a dielectric insulation fluid, where it is a measure of the resistance offered by a fluid to flow. It is important to ensure the viscosity of insulation fluid at operating temperatures is low because the thinner the fluid, the easier it flows [63]. Studies have found that aging and oxidation will increase the viscosity of insulation fluid. The range of viscosities for RBDPO and RBDPO olein are in between $37 \mathrm{cSt}$ to $50 \mathrm{cSt}$ and 21 
cSt to 48.50 cSt, respectively $[16,45,48,61,62,64]$. These values are much lower than crude palm oil, with a value of $54.44 \mathrm{cSt}$, as shown in Table 7 [52].

Table 4. Dielectric dissipation factor of various types of Palm Oil.

\begin{tabular}{l|c} 
Palm Oil & Dielectric dissipation factor at $\mathbf{9 0}{ }^{\circ} \mathbf{C}$ \\
\hline Requirement for transformer fluids [59] & $\leq 0.05$ \\
\hline CPO [48] & Between 0.006 and 0.013 \\
\hline RPO [48] & Between 0.0114 and 0.013 \\
\hline RBDPO [61,62] & Between 0.0035 and 0.014 \\
\hline RBDPO olein $[15,45,61]$ & Between 0.014 and 0.03 \\
& 0.03 at $25^{\circ} \mathrm{C}$
\end{tabular}

Table 5. Resistivity of various types of Palm Oil.

\begin{tabular}{l|c} 
Palm Oil & Resistivity $(\mathbf{\Omega m})$ \\
\hline Requirement for transformer fluids [59] & $\geq 1 \times 10^{12}$ \\
\hline RBDPO [15] & Between 4.01 and 6.22
\end{tabular}

Table 6. Relative permittivity of various types of Palm Oil.

\begin{tabular}{l|c} 
Palm Oil & Relative permittivity at $90{ }^{\circ} \mathbf{C}$ \\
\hline Requirement for transformer fluids [59] & $2.8-3.3$ \\
\hline CPO [62] & 2.1 \\
\hline RBDPO [61,62] & 3.5 \\
\hline RBDPO olein [15,45] & 2.81 \\
& 3.1 at $25^{\circ} \mathrm{C}$
\end{tabular}

Table 7. Viscosity of various types of Palm Oil.

\begin{tabular}{l|c} 
Palm Oil & Viscosity $(\mathbf{c S t})$ at $\mathbf{4 0}{ }^{\circ} \mathbf{C}$ \\
\hline Requirement for transformer fluids [59] & $\leq 50$ \\
\hline CPO [48] & 54.44 \\
\hline RPO ([48] & 42.74 \\
\hline RBDPO [61,62,64] & Between 37 and 50 \\
\hline RBDPO olein $[15,45,49,61]$ & Between 21 and 48.50
\end{tabular}

\subsubsection{Acidity.}

Acidity is another important parameter for dielectric insulating fluids and can be used as a benchmark to evaluate the chemical stability of the insulating fluid. The increase in oil acidity is a good indicator that shows aging has occurred in the transformer in service. Typically, the acidity level is used as a general guide for determining the time for replacement or reclamation of the oil [65-66]. The acidity value could also be affected by the composition of fatty acids. There are only a few studies that have been conducted on the acidity of palm oils. Based on the previous studies, the value of acidity on RBDPO olein is ranging between $0.0014 \mathrm{mgKOH} / \mathrm{g}$ and $0.074 \mathrm{mgKOH} / \mathrm{g}$, which is slightly lower compared to the limit recommended, based on standard IEC 62770 where the value acceptance is $\leq 0.06 \mathrm{mgKOH} / \mathrm{g}$ $[16,45,59,67]$ (Table 8).

Table 8. Acidity of various types of Palm Oil.

\begin{tabular}{l|c} 
Palm Oil & Acidity (mgKOH/g) \\
\hline Requirement for transformer fluids [59] & $\leq 0.06$ \\
\hline RBDPO olein [15] [45] & $0.0014-0.074$
\end{tabular}

\subsubsection{Moisture.}

The main product of aging in dielectric insulation fluid is moisture. However, it is not desired. It can cause serious issues to the transformer if it exceeded a certain acceptable limit. If the moisture is not properly mitigated and reduced, it will shorten the lifetime of transformers. Previous studies reported that the moisture of crude palm oil is $84 \mathrm{ppm}$. The moisture of refined palm oil is $43 \mathrm{ppm}$, which is much lower than RBDPO olein with a value ranging from $105.7 \mathrm{ppm}$ to $125.8 \mathrm{ppm}$ as shown in Table 8 [16,48]. All reported moisture 
values are lower than the recommended limit for natural ester dielectric insulation fluids, which is below 200 ppm [59] (Table 9).

Table 9. Moisture of various types of Palm Oil.

\begin{tabular}{l|c} 
Palm Oil & Moisture (ppm) \\
\hline Requirement for transformer fluids [59] & $\leq 200$ \\
\hline CPO [48] & 84 \\
\hline RPO [48] & 43 \\
\hline RBDPO olein [15] & Between 105.70 and 125.8
\end{tabular}

\subsection{Aging performances of palm oil as a transformer insulation fluid.}

Performances of palm oil are also evaluated in terms of its aging performance. The studies only focus on the investigation of properties of palm oil under thermal aging.

Aging is one of the most crucial characteristics in both the research and commercial operations of transformers. A transformer in-service will eventually undergo an aging process of which the rate depends on many parameters such as temperature, moisture, and oxygen. The aging process will usually lead to different by-products, such as acids, gases, and furanic compounds [68-69]. These by-products could degrade the lifetime of dielectric insulation fluids and will affect the performance of transformers.

Recently, Mohamad et al. [15] reported that there is no significant effect on AC breakdown voltage of palm oil under thermal aging at $85{ }^{\circ} \mathrm{C}$ and $115{ }^{\circ} \mathrm{C}$ [16]. The $\mathrm{AC}$ breakdown voltage of RBDPO Olein maintains at a high level throughout the aging period I, which complies with the required limit recommended by IEEE C57.147 [58], which is $\geq 20 \mathrm{kV}$ at $1 \mathrm{~mm}$ gap distance. In terms of dielectric dissipation factor, only an aging temperature of 85 ${ }^{\circ} \mathrm{C}$ is within the limit recommended by IEC 62770 , which is $\leq 0.05$ at $90{ }^{\circ} \mathrm{C} / 50 \mathrm{~Hz}$. RBDPO olein's resistivity is lower than the limit recommended for transformer insulation fluid at both aging temperatures, as shown in Table 9.3. The relative permittivity of RBDPO olein maintains between 2.82 and 2.86 within the required limit recommended by IEC 62770 [59], which is between 2.8 and 3.3 at $9090{ }^{\circ} \mathrm{C} / 50 \mathrm{~Hz}$. Under the thermal aging, it was found that the viscosity of RBDPO olein remains lower below the required limit recommended by both IEC 62770 [59] and ASTM D6871 [70], which is $\leq 50 \mathrm{~mm} 2 / \mathrm{s}$ at $40{ }^{\circ} \mathrm{C}$ for both aging temperatures. This study reported that the acidity also remains below the required limit $(\leq 0.06 \mathrm{mgKOH} / \mathrm{g})$ suggested by IEC 62770 [59] and ASTM D 6871 [70]. Only at an aging temperature $115^{\circ} \mathrm{C}$, the moisture reduces below the limit recommended by IEC 62770 [59] and ASTM D 6871 [70], which is $\leq$ $200 \mathrm{ppm}$ [48]. Aging performance under various conditions of palm oil is depicted in Table Table 10-16. Data for these tables were adopted from [15].

\subsection{Nanoparticles in Insulation fluid.}

During the early research, nanoparticles were introduced to enhance the capability of fluids in terms of thermal conductivity and heat transfer coefficient [22]. At the moment, several researches have been done to enhance the performance in terms of the electrical, chemical, and physical properties of fluid with nanoparticles' presence. Yet, it is anticipated that palm oil performance as an insulation fluid could be improved by using nanoparticles.

Table 10. AC breakdown voltage of Palm Oil.

\begin{tabular}{l|c|c|c}
\multirow{2}{*}{ Palm Oil } & $\begin{array}{c}\text { Ageing duration } \\
\text { (days) }\end{array}$ & Temperature & $\begin{array}{c}\text { AC breakdown voltage } \\
(\mathbf{k V})\end{array}$ \\
\hline RBDPO olein & $0-14$ & $85^{\circ} \mathrm{C}$ & Between 37.40 and 43.16 \\
\cline { 2 - 3 } & & $115^{\circ} \mathrm{C}$ & Between 38.16 and 48.67
\end{tabular}


Table 11. Dielectric dissipation factor of Palm Oil.

\begin{tabular}{l|c|c|l} 
Palm Oil & Ageing duration (days) & Temperature & Dielectric dissipation factor \\
\hline RBDPO olein & $0-14$ & $85^{\circ} \mathrm{C}$ & Between 0.02 and 0.05 \\
\cline { 2 - 4 } & & $115^{\circ} \mathrm{C}$ & Between 0.05 and 0.07
\end{tabular}

Table 12. Resistivity of Palm Oil.

\begin{tabular}{l|c|c|l} 
Palm Oil & Ageing duration (days) & Temperature & Resistivity $\mathbf{( \Omega m})$ \\
\hline RBDPO olein & $0-14$ days & $85^{\circ} \mathrm{C}$ & Between 2.78E9 and 6.43E9 \\
\cline { 2 - 3 } & & $115^{\circ} \mathrm{C}$ & Between 1.98E9 and 3.34E9
\end{tabular}

Table 13. Relative permittivity of Palm Oil.

\begin{tabular}{l|c|c|l} 
Palm Oil & Ageing duration (days) & Temperature & Relative permittivity \\
\hline RBDPO olein & $0-14$ days & $85^{\circ} \mathrm{C}$ & Between 2.82 and 2.86 \\
\cline { 2 - 3 } & & $115^{\circ} \mathrm{C}$ & Between 2.82 and 2.83
\end{tabular}

Table 14. Viscosity of Palm Oil.

\begin{tabular}{l|c|c|l} 
Palm Oil & Ageing duration (days) & Temperature & Viscosity $(\mathbf{c S t})$ \\
\hline RBDPO olein & $0-14$ days & $85^{\circ} \mathrm{C}$ & Between 36.8 and 38.6 \\
\cline { 2 - 3 } & & $115^{\circ} \mathrm{C}$ & Between 41.1 and 42.8
\end{tabular}

Table 15. Acidity of Palm Oil.

\begin{tabular}{l|c|c|l} 
Palm Oil & Ageing duration (days) & Temperature & Acidity $(\mathbf{m g K O H} / \mathbf{g})$ \\
\hline RBDPO olein & $0-14$ days & $85^{\circ} \mathrm{C}$ & Between 0.001 and 0.004 \\
\cline { 2 - 4 } & & $115^{\circ} \mathrm{C}$ & Between 0.003 and 0.005
\end{tabular}

Table 16. Moisture of Palm Oil.

\begin{tabular}{l|c|c|l} 
Palm Oil & Ageing duration (days) & Temperature & Moisture (ppm) \\
\hline RBDPO olein & $0-14$ days & $85^{\circ} \mathrm{C}$ & Between 153.8 and 332.3 \\
\cline { 2 - 3 } & & $115^{\circ} \mathrm{C}$ & Between 121.1 and 131.0
\end{tabular}

\subsubsection{Types of nanoparticles.}

Nanofluid is defined as a nanotechnology-based fluid in which a few nano-sized materials (nanoparticles) is dispersed in pure fluids such as mineral, vegetable, and ester oil [22] (Table 17). In a simple word, nanofluid is a pure fluid with the presence of nanoparticles. Table 17 shows classification of nanoparticles [71-72].

\subsubsection{Applications of nanoparticles in palm oil.}

In recent years, nanoparticles have been widely used to improve insulation fluid capability in terms of electrical, physical, and chemical properties. Table 18 shows the results of studies done to investigate the electrical properties of insulation with the presence of nanoparticles.

It is anticipated that the electrical performances of insulation fluid could be improved with the presence of nanoparticles. A number of studies have been done on mineral oil and other vegetable oil except for palm oil. For palm oil, the studies have been done only in the investigation of AC breakdown voltage. The results show that the AC breakdown voltage has been increased compared to that of pure palm oil, and it is a good indicator to expand the studies on nanoparticles in palm oil on other electrical and physicochemical properties.

Table 17. Classification of Nanoparticles.

\begin{tabular}{l|l} 
Types & Example \\
\hline Conductive & $\mathrm{SiC}, \mathrm{ZnO}$, and $\mathrm{Fe}_{3} \mathrm{O}_{4}$ \\
\hline Semi-conductive & $\mathrm{Cu}_{2} \mathrm{O}, \mathrm{CuO}$, and $\mathrm{TiO}_{2}$ \\
\hline Insulate & $\mathrm{SiO}_{2}$ and $\mathrm{Al}_{2} \mathrm{O}_{3}$
\end{tabular}


Table 18. Summary of the presence of nanoparticles in oil insulation.

\begin{tabular}{|c|c|c|c|c|}
\hline \multicolumn{2}{|l|}{ Types of oil } & \multirow[t]{2}{*}{$\begin{array}{l}\text { Types of } \\
\text { Nanoparticle }\end{array}$} & \multirow{2}{*}{$\begin{array}{l}\text { Findings } \\
\text { - Improve the AC breakdown voltages of RDBPO and CO. }\end{array}$} & \multirow{2}{*}{$\begin{array}{l}\text { References } \\
{[25]}\end{array}$} \\
\hline $\begin{array}{l}\text { Palm Oil and } \\
\text { Coconut oil }\end{array}$ & $\begin{array}{ll}\text { Refined, } & \\
\text { Bleached and } \\
\text { Deodorized } \\
\text { Palm } \\
(\text { RBDPO) }\end{array}$ & & & \\
\hline \multirow{3}{*}{ Palm Oil } & \multirow{3}{*}{$\begin{array}{l}\text { Palm fatty acids } \\
\text { ester (PFAE) }\end{array}$} & \multirow{3}{*}{$\mathrm{Fe}_{3} \mathrm{O}_{4}$} & $\begin{array}{l}\text { - Improve the breakdown voltage and good performances } \\
\text { under moisture stress. }\end{array}$ & [73] \\
\hline & & & $\begin{array}{l}\text { - Improve the AC breakdown voltage for all PFAE-based } \\
\text { nanofluids. }\end{array}$ & {$[15]$} \\
\hline & & & $\begin{array}{l}\text { - } 0.01 \% \text { Iron Oxide dispersed in ester oil has reduced AC } \\
\text { breakdown voltage. } \\
\text { - However, both samples } 0.02 \% \text { and } 0.03 \% \text { Iron Oxide } \\
\text { dispersed in ester oil has increased the AC breakdown voltage. }\end{array}$ & {$[31]$} \\
\hline \multirow[b]{2}{*}{$\begin{array}{l}\text { Soybean oil } \\
\text { (FR3) }\end{array}$} & \multirow[b]{2}{*}{-} & $\mathrm{SiO}_{2}$ & $\begin{array}{l}\text { - Improve the dielectric performance characteristics. } \\
\text { - Useful for enhancing the dielectric characteristics of } \\
\text { transformers. }\end{array}$ & [26] \\
\hline & & $\mathrm{TiO}_{2}$ & $\begin{array}{l}\text { - Can accelerate the charge dissipation rate and uniform the } \\
\text { electric field. } \\
\text { - Increase the shallow trap density in the ester-based } \\
\text { nanofluid. }\end{array}$ & {$[60]$} \\
\hline \multirow{4}{*}{ Mineral Oil } & \multirow{4}{*}{-} & $\begin{array}{l}\mathrm{TiO}_{2}, \mathrm{BaTiO}_{3}, \\
\mathrm{ZnO}\end{array}$ & $\begin{array}{l}\text { - Improve the AC breakdown voltage for Mineral Oil. } \\
\text { - Good for dielectric applications. }\end{array}$ & [24] \\
\hline & & \multirow[b]{2}{*}{$\mathrm{SiO}_{2}$} & - Improve the PD performance characteristics. & {$[74]$} \\
\hline & & & $\begin{array}{l}\text { - Improve the breakdown strength, especially at high } \\
\text { moisture content level. }\end{array}$ & {$[22,23]$} \\
\hline & & $\begin{array}{l}\mathrm{SiO}_{2}, \\
\mathrm{ZnO}\end{array}$ & $\begin{array}{l}\text { - Improve the breakdown voltage with increase in particle } \\
\text { volume fractions. }\end{array}$ & [75] \\
\hline Vegetable oil & - & $\mathrm{Fe}_{3} \mathrm{O}_{4}$ & $\begin{array}{l}\text { With increasing the nanoparticle size: } \\
\text { - Improve the breakdown performance of nanofluids. } \\
\text { - The volume resistivities of the nanofluids are almost } \\
\text { equal. } \\
\text { - The dissipation factors increase at frequencies below } \\
0.1 \mathrm{~Hz} \text {. } \\
\text { - The relative permittivity of the nanofluids are greater than } \\
\text { the FR3 oil. } \\
\text { - Increase the electrical potential well depth. } \\
\text { - Enhance the capability of breakdown performance of } \\
\text { nanofluids. }\end{array}$ & [76] \\
\hline
\end{tabular}

\section{Conclusions}

This study gives an overview of the applicability of palm oil as a transformer insulation fluid. A comprehensive analysis has been provided in terms of the properties and performances of palm oil. It is anticipated that palm oil is a good candidate as an alternative fluid for replacing mineral oil in transformer applications. Basically, for transformer oil, the electrical and physicochemical properties of palm oil are of prime concern. In terms of electrical properties, the performance of AC breakdown voltage of palm oil meets the requirements set forth by IEC standard. The lightning impulse breakdown voltage characteristics of palm oil also fulfill the recommendations of IEC 60897. In terms of dielectric properties, such as the dielectric dissipation factor, palm oil has a value in the range of 0.0035 to 0.03 ; thus, it is in compliance with the IEC standards' recommendations. For resistivity and relative permittivity, the values are within limits. In terms of physicochemical properties such as viscosity, palm oil again meets the limit. The acidity of RBDPO olein ranges between $0.0014 \mathrm{mgKOH} / \mathrm{g}$ and $0.074 \mathrm{mgKOH} / \mathrm{g}$, which is slightly lower than the limit specified in IEC 62770 [59] where the accepted maximum is 0.06 , and for the moisture of palm oil, it has been found that the value is lower than the recommended limit suggested for natural ester dielectric insulation fluids (which is below 200 
ppm). Performances of palm oil under aging show reasonably good results. There is not much difference between the AC breakdown voltage values between no aging and 14-day aging, which indicates that palm oil shows no degradation after this specified aging. However, further durations of aging should be tested in order to have a better understanding of the aging performance of palm oil. For the application of nanoparticles in palm oil, it is anticipated that palm oil performances could be improved in terms of electrical, physical, and chemical properties. Future prospects of palm oil, being utilized as an alternative insulation fluid to replace mineral oil, are quite high. Based on the previous studies' results, it is evident that palm oil meets the requirement of international standards and a majority of the electrical, physical and chemical properties are comparable with that of mineral oil. However, there are several lapses in the studies on palm oil as a transformer fluid. One of them is the lack of investigation on the partial discharge. Partial discharge is a critical component that can cause deterioration of insulation fluids in transformers, which leads to a partial breakdown. Such studies are essential in making improvements in the life of oil insulation. There is also a lack of studies on the lightning impulse breakdown voltage of palm oil. At the moment, few studies have been conducted elsewhere in investigating the lightning breakdown voltage of palm oil. It is crucial to examine the lightning impulse breakdown voltage due to the possibilities of direct lightning current injection and overvoltage occurring in transformers' real-life. The studies on insulation fluids in the presence of nanoparticles are conducted by many research groups; however, their attention on palm oil is yet to be triggered. The studies have only been done concerning AC breakdown voltage so far. Thus, further studies of palm oil in the presence of nanoparticles should be conducted comprehensively. The research on palm oil as a transformer fluid is still going on, and it requires further attention of the scientific community, as the oil may have a significant contribution to the reduction of environmental impact by mineral oils.

\section{Funding}

This research received no external funding.

\section{Acknowledgments}

The authors would like to thank the Faculty of Engineering, Universiti Putra Malaysia, the School of Electrical and Information Engineering, University of the Witwatersrand and EPPEIHVAC for placing excellent research facilities to make this work a success.

\section{Conflicts of Interest}

The authors declare no conflict of interest.

\section{References}

1. Padfield, R.; Hansen, S.; Davies, Z.G.; Ehrensperger, A.; Slade, E.M.; Evers, S.; Papargyropoulou, E.; Bessou, C.; Abdullah, N.; Page, S.; Ancrenaz, M.; Aplin, P.; Dzulkafli, S.B.; Barclay, H.; Chellaiah, D.; Choudhary, S.; Conway, S.; Cook, S.; Copeland, A.; Campos-Arceiz, A.; Deere, N.J.; Drew, S.; Gilvear, D.; Gray, R.; Haller, T.; Hood, A.S.C.; Huat, L.K.; Huynh, N.; Kangayatkarasu, N.; Koh, L.P.; Kolandai, S.K.; Lim, R.A.H.; Yeong, K.L.; Lucey, J.M.; Luke, S.H.; Mitchell, S.L.; Montefrio, M.J.; Mullin, K.; Nainar, A.; Nekaris, K.A.-I.; Nijman, V.; Nunes, M.; Nurhidayu, S.; O'Reilly, P.; Puan, C.L.; Ruppert, N.; Salim, H.; Schouten, G.; Tallontire, A.; Smith, T.E.L.; Tao, H.-H.; Tham, M.H.; Varkkey, H.; Wadey, J.; Yule, C.M.; Azhar, B.; Sayok, A.K.; Vairappan, C.; Bicknell, J.E.; Struebig, M.J. Co-producing a Research Agenda for Sustainable Palm Oil. Frontiers in Forests and Global Change 2019, 2, 1-13, https://doi.org/10.3389/ffgc.2019.00013. 
2. Kangpanich, C.; Pratoomyot, J.; Senanan, W. Effects of alternative oil sources in feed on growth and fatty acid composition of juvenile giant river prawn (Macrobrachium rosenbergii). Agriculture and Natural Resources 2017, 51, 103-108, https://doi.org/10.1016/j.anres.2016.12.004.

3. Chowtivannakul, P.; Srichaikul, B.; Talubmook, C. Antidiabetic and antioxidant activities of seed extract from Leucaena leucocephala (Lam.) de Wit. Agriculture and Natural Resources 2016, 50, 357-361, https://doi.org/10.1016/j.anres.2016.06.007.

4. Maimulyanti, A.; Prihadi, A.R. Chemical composition of essential oil and hexane extract and antioxidant activity of various extracts of Acmella uliginosa ( $\mathrm{Sw}$.) Cass flowers from Indonesia. Agriculture and Natural Resources 2016, 50, 264-269, https://doi.org/10.1016/j.anres.2015.11.002.

5. Yahaya, M.S.; Raof, N.A.; Ibrahim, Z.; Ahmad, A.; Gomes, C. Modifications required for palm oil to be qualified as a mechanical lubricant. International Journal of Manufacturing, Materials, and Mechanical Engineering 2019, 9, 50-66, https://doi.org/10.4018/IJMMME.2019010104.

6. Phadungthin, R.; Haema, J. Proposed Risk Model of Maintenance Management for Power Transformer in Transmission System. International Review of Electrical Engineering (IREE) 2016, 11, https://doi.org/10.15866/iree.v11i1.7703.

7. Ghoneim, S. A Fuzzy Diagnostic System for Incipient Transformer Faults Based on DGA of the Insulating Transformer Oils. International Review of Electrical Engineering 2016, 11, 305-313, https://doi.org/10.15866/iree.v11i3.8453.

8. Katim, N.I.; Ishak, M.T.; Mohamad Amin, N.A.; Abdul Hamid, M.H.; Amali Ahmad, K.; Azis, N. Lightning Breakdown Voltage Evaluation of Palm Oil and Coconut Oil as Transformer Oil under Quasi-Uniform Field Conditions. Energies 2018, 11, https://doi.org/10.3390/en11102676.

9. Martin, D.; Saha, T.; Mcpherson, L. Condition monitoring of vegetable oil insulation in in-service power transformers: some data spanning 10 years. IEEE Electrical Insulation Magazine 2017, 33, 44-51, https://doi.org/10.1109/MEI.2017.7866678.

10. Aljure, M.; Becerra, M.; Karlsson, M.E. On the injection and generation of charge carriers in mineral oil under high electric fields. Journal of Physics Communications 2019, 3, https://doi.org/10.1088/23996528/ab0d59.

11. Abdullahi, U.U.; Bashi, S.M.; Yunus, R.; Mohibullah; Nurdin, H.A. The potentials of palm oil as a dielectric fluid. In Proceedings of PECon 2004. Proceedings. National Power and Energy Conference, 2004., 29-30 Nov. 2004; pp. 224-228, https://doi.org/10.1109/PECON.2004.1461648.

12. Azmi, K.; Ahmad, A.; Kamarol, M. Study of Dielectric Properties of a Potential RBD Palm Oil and RBD Soybean Oil Mixture as Insulating Liquid in Transformer. Journal of Electrical Engineering and Technology 2015, 10, 2105-2119, https://doi.org/10.5370/JEET.2014.9.2.662.

13. Bashi, S.; Abdullahi, U.U.; Yunus, R.; Nordin, A. Use of natural vegetable oils as alternative dielectric transformer coolants. Journal of the The Institution of Engineers Malaysia 2006, 67, 4-9.

14. Mohamad, N.A.; Azis, N.; Jasni, J.; Kadir, M.Z.A.A.; Yunus, R.; Ishak, M.T.; Yaakub, Z. A study on the dielectric properties of Palm Oil and Coconut Oil. In: Proceedings of 2014 IEEE International Conference on Power and Energy (PECon). 1-3 Dec. 2014; pp. 109-112, https://doi.org/10.1109/PECON.2014.7062423.

15. Mohamad, A.; Azis, N.; Jasni, J.; Kadir, Z.; Yunus, R.; Ishak, M.; Yaakub, Z. Investigation on the Dielectric, Physical and Chemical Properties of Palm Oil and Coconut Oil under Open Thermal Ageing Condition. Journal of Electrical Engineering and Technology 2016, 11, 709-718, https://doi.org/10.5370/JEET.2016.11.3.690.

16. Mohamad Nur, A.; Azis, N.; Jasni, J.; Kadir Mohd Zainal Abidin, A.; Yunus, R.; Yaakub, Z. Effect of surfactants on the lightning breakdown voltage of palm oil and coconut oil based Al2O3 nanofluids. Nanotechnology 2020, 31(42), 425708, https://doi.org/10.1088/1361-6528/aba1b9.

17. Totzauer, P.; Trnka, P. Different Ways to Improve Natural Ester Oils. Transportation Research Procedia 2019, 40, 102-106, https://doi.org/10.1016/j.trpro.2019.07.017.

18. Katim, N.I.A.; Ishak, M.T.; Ishak, A.M.; Thein, Y.V.; Azis, N.; Kadir, M.Z.A.A.; Jasni, J.; Yunus, R.; Yaakub, Z. Examination on the lightning breakdown strength of biodegradable oil under quasi-uniform field. In: Proceedings of 2014 IEEE International Conference on Power and Energy (PECon). 1-3 Dec. 2014; pp. 17-20, https://doi.org/10.1109/PECON.2014.7062406.

19. Kadim, I.A.H. Study the electrical stress withstand properties of heated refined bleached and deodorized palm oil dielectrics. Master Thesis, Universiti Tun Hussein Onn Malaysia. 2015.

20. Jeong, J.; An, J.; Huh, C. Accelerated aging effects of mineral and vegetable transformer oils on medium voltage power transformers. IEEE Transactions on Dielectrics and Electrical Insulation 2012, 19, 156-161, https://doi.org/10.1109/TDEI.2012.6148514.

21. Du, B.; Li, J.; Wang, F.; Yao, W.; Yao, S. Influence of Monodisperse Fe 3 O 4 Nanoparticle Size on Electrical Properties of Vegetable Oil-Based Nanofluids. Journal of Nanomaterials 2015, 2015, https://doi.org/10.1155/2015/560352.

22. Jin, H.; Andritsch, T.; Morshuis, P.H.F.; Smit, J.J. AC breakdown voltage and viscosity of mineral oil based $\mathrm{SiO} 2$ nanofluids. In: Proceedings of 2012 Annual Report Conference on Electrical Insulation and Dielectric Phenomena. 14-17 Oct. 2012; pp. 902-905, https://doi.org/10.1109/CEIDP.2012.6378927. 
23. Jin, H.; Andritsch, T.; Tsekmes, I.A.; Kochetov, R.; Morshuis, P.H.F.; Smit, J.J. Properties of Mineral Oil based Silica Nanofluids. IEEE Transactions on Dielectrics and Electrical Insulation 2014, 21, 1100-1108, https://doi.org/10.1109/TDEI.2014.6832254.

24. Muangpratoom, P.; Pattanadech, N. Dielectric breakdown strength of mineral oil based nanofluids. In: Proceedings of 2016 International Conference on Condition Monitoring and Diagnosis (CMD). 25-28 Sept. 2016; pp. 266-269.https://doi.org/10.1109/CMD.2016.7757836.

25. Nor, S.F.M.; Azis, N.; Jasni, J.; Kadir, M.Z.A.A.; Yunus, R.; Ishak, M.T.; Yaakub, Z. A study on the AC breakdown voltages of as-received palm oil and coconut oil under presence of TiO2. In: Proceedings of 2015 IEEE Conference on Energy Conversion (CENCON). 19-20 Oct. 2015; pp. 354-357, https://doi.org/10.1109/CENCON.2015.7409568.

26. Prasad, D.; Chandrasekar, S. Investigations on Dielectric Performance Characteristics of Natural Ester based Nano-Fluids for Power Transformer Applications. Asian Journal of Research in Social Sciences and Humanities 2016, 6, 1146-1157, https://doi.org/10.5958/2249-7315.2016.01259.4.

27. Dombek, G.; Goscinski, P.; Nadolny, Z. Comparison of mineral oil and esters as cooling liquids in high voltage transformer in aspect of environment protection. E3S Web Conf. 2017, 14, https://doi.org/10.1051/e3sconf/20171401053.

28. Gnanasekaran, D.; Chavidi, V.P. Vegetable Oil based Bio-lubricants and Transformer Fluids. Materials Forming, Machining and Tribology. Springer Nature Singapore, 2018.

29. Mehta, D.M.; Kundu, P.; Chowdhury, A.; Lakhiani, V.K.; Jhala, A.S. A review on critical evaluation of natural ester vis-a-vis mineral oil insulating liquid for use in transformers: Part 1. IEEE Transactions on Dielectrics and Electrical Insulation 2016, 23, 873-880, https://doi.org/10.1109/TDEI.2015.005370.

30. Evangelista, J.M.; Bortot Coelho, F.E.; Carvalho, J.; Araújo, E.; Miranda, T.; Salum, A. Development of a New Bio-Based Insulating Fluid from Jatropha curcas Oil for Power Transformers. Advances in Chemical Engineering and Science 2017, 07, 235-255, https://doi.org/10.4236/aces.2017.72018.

31. Mohamad, M.S.; Zainuddin, H.; Ghani, S.A.; Chairul, I.S. AC breakdown voltage of natural ester mixed with Iron Oxide for oil-immersed power transformer application. In: Proceedings of 2015 IEEE Student Conference on Research and Development (SCOReD). 13-14 Dec. 2015; pp. 16-20; https://doi.org/10.1109/SCORED.2015.7449315.

32. Fal, J.; Mahian, O.; Żyła, G. Nanofluids in the Service of High Voltage Transformers: Breakdown Properties of Transformer Oils with Nanoparticles, a Review. Energies 2018, 11, https://doi.org/10.3390/en11112942.

33. Teng, S.; Khong, K.W.; Che Ha, N. Palm oil and its environmental impacts: A big data analytics study. Journal of Cleaner Production 2020, 274, https://doi.org/10.1016/j.jclepro.2020.122901.

34. Sambanthamurthi, R.; Sundram, K.; Tan, Y.-A. Chemistry and biochemistry of palm oil. Progress in Lipid Research 2000, 39, 507-558, https://doi.org/10.1016/S0163-7827(00)00015-1.

35. Abdelmalik, A.A.; Fothergill, J.C.; Dodd, S.J. Electrical conduction and dielectric breakdown characteristics of alkyl ester dielectric fluids obtained from palm kernel oil. IEEE Transactions on Dielectrics and Electrical Insulation 2012, 19, 1623-1632, https://doi.org/10.1109/TDEI.2012.6311509.

36. Kano, T.; Suzuki, T.; Oba, R.; Kanetani, A.; Koide, H. Study on the oxidative stability of palm fatty acid ester (PFAE) as an insulating oil for transformers. In: Proceedings of 2012 IEEE International Symposium on Electrical Insulation. 10-13 June 2012; pp. 22-25, https://doi.org/10.1109/ELINSL.2012.6251418.

37. Takaaki, K.; Hiroyuki, I.; Yoshiyuki, H.; Junichi, Y.; Tomoyuki, H.; Akina, Y.; Yasunori, H.; Hidenobu, K. Analyses of electro-chemical characteristics of Palm Fatty Acid Esters as insulating oil. In: Proceedings of 2008 IEEE International Conference on Dielectric Liquids. 30 June-3 July 2008; pp. 1-4, https://doi.org/10.1109/ICDL.2008.4622456.

38. Srinivasa, D.M.; Surendra, U. Comparative study of Breakdown Phenomena and Viscosity in Liquid Dielectrics. In: Proceedings of 2019 Innovations in Power and Advanced Computing Technologies (iPACT). 22-23 March 2019; pp. 1-4, https://doi.org/10.1109/i-PACT44901.2019.8960134.

39. Mohamad, N.A.; Azis, N.; Jasni, J.; Ab. Kadir, M.Z.A.; Yunus, R.; Yaakub, Z. Effect of surfactants on the lightning breakdown voltage of palm oil and coconut oil based Al2O3 nanofluids. Nanotechnology 2020, 31, https://doi.org/10.1088/1361-6528/aba1b9.

40. ASTM D1816: Standard Test Method for Dielectric Breakdown Voltage of Insulating Liquids Using VDE Electrodes, USA, 2019.

41. IEC 60156, Insulating liquids: Determination of the breakdown voltage at power frequency - Test method. Malaysia: Department Of Standards Malaysia, 2018.

42. IEC 60296 International Standards, Fluids for Electrotechnical Applications-Unused Mineral Insulating Oils for Transformers and Switchgears, 2020

43. Hernandez-Herrera, H.; Silva-Ortega, J.I.; Mejia-Taboada, M.; Diaz Jacome, A.; Torregroza-Rosas, M. Natural ester fluids applications in transformers as a sustainable dielectric and coolant. AIP Conference Proceedings 2019, 2123, https://doi.org/10.1063/1.5116976.

44. Azis, N.; Jasni, J.; Kadir Mohd Zainal Abidin, A.; Mohtar Mohd, N. Suitability of Palm Based Oil as Dielectric Insulating Fluid in Transformers. Journal of Electrical Engineering and Technology 2014, 9, 662669, https://doi.org/10.5370/JEET.2014.9.2.662. 
45. Rajab, A.; Aminuddin, S.; Suwarno. Properties of RBDPO Oleum as a candidate of palm based-transformer insulating liquid. In: Proceedings of 2009 International Conference on Electrical Engineering and Informatics. 5-7 Aug. 2009; pp. 548-552, https://doi.org/10.1109/ICEEI.2009.5254755.

46. Gesteiro, E.; Guijarro, L.; Sánchez-Muniz, F.J.; Vidal-Carou, M.D.; Troncoso, A.; Venanci, L.; Jimeno, V.; Quilez, J.; Anadón, A.; González-Gross, M. Palm Oil on the Edge. Nutrients 2019, 11, https://doi.org/10.3390/nu11092008.

47. Mozzon, M.; Foligni, R.; Mannozzi, C. Current Knowledge on Interspecific Hybrid Palm Oils as Food and Food Ingredient. Foods 2020, 9, https://doi.org/10.3390/foods9050631.

48. Yaacob, M.; Alsaedi, M. Use Palm Oil as Alternative with Insulation Oil in High Voltage Equipment. Physical Science International Journal 2015, 5, 172-178, https://doi.org/10.9734/PSIJ/2015/12790.

49. IEEE Guide for Improving the Lightning Performance of Electric Power Overhead Distribution Lines, Institute of Electrical and Electronics Engineers: IEEE Standards Association, 2011.

50. Ramarao, G.; Chandrasekaran, K. Representation of Severe Negative Subsequent Return Stroke by Optimization based Channel-Base-Current Function Parameters. Materials Today: Proceedings 2019, 11, 1079-1087, https://doi.org/10.1016/j.matpr.2018.12.042.

51. Gomes, C.; Cooray, V. Concepts of lightning return stroke models. IEEE Transactions on Electromagnetic Compatibility 2000, 42, 82-96, https://doi.org/10.1109/15.831708.

52. Liu, Q.; Wang, Z.D. Breakdown and withstand strengths of ester transformer liquids in a quasi-uniform field under impulse voltages. IEEE Transactions on Dielectrics and Electrical Insulation 2013, 20, 571-579, https://doi.org/10.1109/TDEI.2013.6508761.

53. Erdogan, M.; Eker, M.K. Analysis of lightning impulse voltage distribution for a dry-type transformer using three different winding types. Electric Power Systems Research 2020, 188, https://doi.org/10.1016/j.epsr.2020.106527.

54. ASTM D3300: Standard Test Method for Dielectric Breakdown Voltage of Insulating Oils of Petroleum Origin Under Impulse Conditions, USA, 2020.

55. IEC 60897: Methods for the determination of the lightning impulse breakdown voltage of insulating liquids: International Electrotechnical Commission, 1987.

56. Thien, Y.V.; Azis, N.; Jasni, J.; Ab Kadir, M.Z.A.; Yunus, R.; Ishak, M.T.; Yaakub, Z. The effect of polarity on the lightning breakdown voltages of palm oil and coconut oil under a non-uniform field for transformers application. Industrial Crops and Products 2016, 89, 250-256, https://doi.org/10.1016/j.indcrop.2016.04.061.

57. IEC 60247: Measurement of Relative Permitivity, Dielectric Dissipation Factor and D.C. Resistivity of Insulating Liquids, 2004.

58. IEEE C57.147-2008. I.S.: IEEE Guide for Acceptance and Maintenance of Natural Ester Fluids in Transformers. IEEE Power and Energy Society,

59. IEC 62770 -2013: Fluids for electrotechnical applications - Unused natural esters for transformers and similar electrical equipment.

60. Qian, Y.-H.; Huang, Y.-B.; Fu, Q.; Zhong, Z.-S. Study on Aging Characteristics and Chemical Composition of Hydrogenated Transformer Oil. Journal of Electrical Engineering and Technology 2013, 8, 588-594, https://doi.org/10.5370/JEET.2013.8.3.588.

61. Aditama, S. Dielectric properties of palm oils as liquid insulating materials: effects of fat content. In: Proceedings of Proceedings of 2005 International Symposium on Electrical Insulating Materials. 2005. (ISEIM 2005). Volume 91, 5-9 June 2005; pp. 91-94, https://doi.org/10.1109/ISEIM.2005.193334.

62. Suwarno; Sitinjak, F.; Suhariadi, I.; Imsak, L. Study on the characteristics of palm oil and it's derivatives as liquid insulating materials. In Proceedings of Proceedings of the 7th International Conference on Properties and Applications of Dielectric Materials (Cat. No.03CH37417), Volumr 492, 1-5 June 2003; pp. 495-498, https://doi.org/10.1109/ICPADM.2003.1218461.

63. Rouabeh, J.; M'Barki, L.; Hammami, A.; Jallouli, I.; Driss, A. Studies of different types of insulating oils and their mixtures as an alternative to mineral oil for cooling power transformers. Heliyon 2019, 5, https://doi.org/10.1016/j.heliyon.2019.e01159.

64. Kiasatina; Kamarol, M.; Zulhilmey, M.; Arief, Y.A. Breakdown characteristics of RBDPO and soybean oil mixture for transformer application. In Proceedings of International Conference on Electrical, Control and Computer Engineering $2011 \quad$ (InECCE), 21-22 June 2011; pp. 219-222, https://doi.org/10.1109/INECCE.2011.5953879.

65. Yang, L.; Liao, R.; Sun, C.; Sun, H. Influence of natural ester on thermal aging characteristics of oil-paper in power transformers. European Transactions on Electrical Power 2010, 20, 1223-1236, https://doi.org/10.1002/etep.398.

66. Awogbemi, O.; Onuh, E.I.; Inambao, F.L. Comparative study of properties and fatty acid composition of some neat vegetable oils and waste cooking oils. International Journal of Low-Carbon Technologies 2019, 14, 417-425, https://doi.org/10.1093/ijlct/ctz038.

67. Ahmad, H.; Mee, M.; Noor, A.; Yusoff, M. Thermal Stability Evaluation of Refined Bleached Deodorized Palm Oil (RBDPO) from Different Refining Parameters for Standard Crude Palm Oil. ETP International Journal of Food Engineering 2018, 4, 36-39, https://doi.org/10.18178/ijfe.4.1.36-39. 
68. Emsley, A.M.; Stevens, G.C. Kinetics and mechanisms of the low-temperature degradation of cellulose. Cellulose 1994, 1, 26-56, https://doi.org/10.1007/BF00818797.

69. Małachowska, E.; Dubowik, M.; Boruszewski, P.; Łojewska, J.; Przybysz, P. Influence of lignin content in cellulose pulp on paper durability. Scientific Reports 2020, 10, https://doi.org/10.1038/s41598-020-771012.

70. ASTM D6871 - 2008: Standard Specification for Natural (Vegetable Oil) Ester Fluids Used in Electrical Apparatus, USA.

71. Rafiq, M.; Lv, Y.; Li, C. A Review on Properties, Opportunities, and Challenges of Transformer Oil-Based Nanofluids. Journal of Nanomaterials 2016, 2016, 1-23, https://doi.org/10.1155/2016/8371560.

72. Rafiq, M.; Shafique, M.; Azam, A.; Ateeq, M.; Khan, I.A.; Hussain, A. Sustainable, Renewable and Environmental-Friendly Insulation Systems for High Voltages Applications. Molecules 2020, 25, https://doi.org/10.3390/molecules2517390.

73. Saad, M.H. Effect of moisture level to AC breakdown voltage of PFAE based nanofluids. Project Report. UTeM, Melaka, Malaysia, 2015.

74. Sankarganesh, R.; Phd, S.; Chandrasekar, S. Analysis of Partial Discharge Signal Characteristics of NanoMineral Oil for Transformer Condition Monitoring Applications. Asian Journal of Research in Social Sciences and Humanities 2016, 6, 341-357, https://doi.org/10.5958/2249-7315.2016.00430.5.

75. Bakrutheen, M.; Karthik, R.; Madavan, R. Investigation of critical parameters of insulating mineral oil using semi-conductive nanoparticles. In: Proceedings of 2013 International Conference on Circuits, Power and Computing Technologies (ICCPCT). 20-21 March 2013; pp. 294-299, https://doi.org/10.1109/ICCPCT.2013.6529039.

76. Du, B.; Li, J.; Wang, F.; Yao, W.; Yao, S. Influence of Monodisperse Fe 3 O 4 Nanoparticle Size on Electrical Properties of Vegetable Oil-Based Nanofluids. Journal of Nanomaterials 2015, 2015, https://doi.org/10.1155/2015/560352. 